Marja Kuittinen, Heta Mikkonen, Tuulevi Ovaska.

Katri Rintamäki ja Tomi Rosti

\title{
LIBER-KONFERENSSI JUHLISTI VIISIKYMPPISIÄÄN VERKOSSA
}

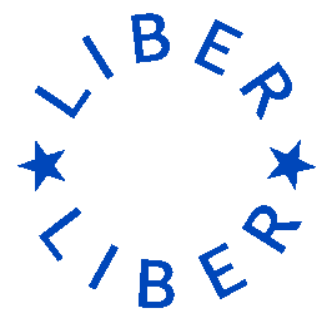

Kesän LIBER-konferenssi järjestettiin teemalla Kirjastot ja avoin tieto: Visiosta toteutukseen. Konferenssin keskeisiä aiheita olivat digitaalisen kirjasto ja tutkimuksen tarpeet, avoin toimintakulttuuri, avoin julkaiseminen ja avoin data. Päivät tarjosivat kiinnostavan näkymän tämän päivän tieteellisten kirjastojen ja tutkimuspalveluiden asiantuntijatyöhön.

V iideskymmenes LIBER-konferenssi järjestettiin maksuttomana verkossa 23.-25.6.202I. Juhlavuoden tapahtuman organisoijana oli eurooppalaisten tutkimuskirjastojen järjestön LIBER:in (Ligue des Bibliothèques Européennes de Recherche) lisäksi Belgradin yliopiston kirjasto.

Tapahtuma koostui monipuolisesta ohjelmasta, joka sisälsi asiantuntijapuheenvuoroja, paneelikeskusteluja, työpajoja ja teemoittaisia rinnakkaistapahtumia. Päiviin oli sisällytetty taukoja, sponsoreiden puheenvuoroja ja sosiaalista ohjelmaa, kuten live-tapahtumissakin. Juhlavuoden kunniaksi avajaistapahtumissa esitettiin entisten LIBER-puheenjohtajien videotervehdys. Konferenssin aineisto, johon tässäkin artikkelissa viitataan, on saatavilla LIBER:in verkkosivulta: https:// liberconference.eu/liber-202 I-presentations-posters/.

\section{Digitaalinen kirjasto ja tutkimuksen tarpeet}

Toma Tasovac pohti asiantuntijapuheenvuorossa klassisen kirjaston suhdetta nykyiseen kirjastomaailmaan, jossa perinteinen teksti ja kuva eivät välttämättä muodosta pysyvää kokonaisuutta, vaan toimivat ennen kaikkea palveluina ja vuorovaikutteisina kokonaisuuksina. Digitaaliset kokoelmat nähdään enemmän tiedonlouhinnan työkaluina ja mahdollistavat digitaalisen humanistisen tutkimuksen tehokkaammin. Kirjastojen uudenlainen toimintatapa voisi mahdollistaa digitaalisten aineistojen kehittymisen ja kirjastot voisivat tuottaa palveluita aineistojen rikastamiseen ja erilaisten palveluiden yhdistämiseen.

Digitalisoituminen muuttaa tutkimuksen tekotapoja ja siirtää sen pois kirjastoista, koska sisällöt eivät ole ainoastaan lehtiartikkeleita tai monografioita vaan aineisto- ja palvelukokonaisuuksia. Tutkimustyön kehittymisen rinnalle tarvitaan uudenlaisia viittaustapoja, jotka mahdollistavat hienojakoisemman ja dynaamiseen sisältöön viittaamisen, joten kirjastojen rooli on edelleen tukea tiedonhankintaa ja -hallintaa. Digitaalisten kirjastojen ja aineistojen kehittäminen lisää uudenlaisen osaamisen tarvetta, kuten tekijänoikeudellisten asioiden vaiku- 
tukset digitaalisten aineistojen hyödyntämiseen ja kirjastojen mahdollisuudet tarjota digitaalisten kokoelmien sisältöjä eri käyttäjäjoukoille.

Digitaalinen ympäristö haastaa tutkimuksen vapautta. Tieteellisissä kirjastoissa on havahduttu siihen, että palveluiden hyödyntäminen onnistui aikaisemmin IP-pohjaisilla tunnistuspalveluilla, mutta nykyisin palveluntarjoajat haluavat hyödyntää kertakirjautumista tai muita kirjautumistapoja lisäpalveluita tarjotakseen. Tällöin käyttäjät ovat enenevissä määrin tunnistettavissa ja luottamuksellisuus käyttäjän ja aineiston välillä katoaa. Tällöin sensitiiviset tutkimusaiheet, aineiston käyttö ja tutkijoiden henkilöllisyys ovat helposti yhdistettävissä. Kirjastoja on perinteisesti pidetty luotettavana paikkana asioida ja edelleenkin oletetaan, että kirjasto tarjoaa luotettavan paikan myös verkkoasiointiin suojellakseen asiakkaitaan.

\section{Dynaamisia digitaalisia kokoelmia}

Dynaamisia digitaalisia kokoelmia esiteltiin kolmen esimerkkitapauksen kautta. Liisa Maria Näpärä Kansalliskirjastosta kertoi Digitaalinen avoin muisti (DAM) -hankkeesta, jossa määritellään uudelleen Kansalliskirjaston roolia tutkimustoiminnassa; edistetään tutkijoiden tietämystä digitaalisten kokoelmien sisällöstä ja niiden tekijänoikeuksista; vahvistetaan Kansalliskirjaston mahdollisuuksia tarjota kokoelmia ja tukea tutkijoille; ja kehi- tetään tutkijoiden ja kirjastojen välistä viestintää ja yhteistyötä.

Constance Rinaldo ja Jane Smith Lontoon luonnonhistoriallisesta museosta kertoivat vuonna 2007 perustetusta Biodiversity Heritage Library (BHL) -virtuaalikirjastosta. Korona-aika toi esille virtuaalikirjaston ansiot virtuaalisen yhteistyön ja tieteen avoimuuden mahdollistamisessa. Samalla korostui tarve kehittää virtuaalikirjastoa ja sen kokoelmia edelleen yhdenvertaisesti kaikkia tiedontarvitsijoita ajatellen. Bruno Forment kertoi Gentin Orpheus-Instituutin Ton Koopman -kokoelman muuttamisesta avoimeksi, digitaaliseksi kokoelmaksi palvelemaan musiikin taiteellista tutkimusta niin Belgiassa kuin ulkomaillakin.

Posterit olivat esillä hyvissä ajoin ennen konferenssia ja esiteltiin myös suullisesti Q\&A-sessiossa. Recreating Europe -hankkeen työ käsitteli tekijänoikeuslainsäädännön ja avoimuuslinjausten vaikutuksia arkisto-, kirjasto- ja museoalojen digitointikäytäntöihin. Alankomaiden kansalliskirjaston posterin aiheena oli digitaalisten historiallisten kokoelmien rikastaminen muun muassa visualisointien ja meemien avulla.

\section{Avoimesta tieteestä kohti avointa tietoa}

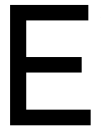
va Méndez tarkasteli laajassa esityksessään kirjastojen haasteita avoimen tiedon instituutioiden luomisessa siirryttäessä avoimesta tieteestä kohti jaettuun tietoon perus- 
tuvaa tutkimusjärjestelmää vuoteen 2030 mennessä. Méndez käytti metaforana Sveitsin armeijan linkkuveitsen tyyppistä monitoimityökalua, jollaista tarvitaan avoimuuden saavuttamiseksi alati muuttuvassa ympäristössä. Kirjastoammattilaisten tulee auttaa tutkijoita, vaikka vastauksia ei välttämättä ole aina tarjolla, sillä muutos ei tapahdu itsestään.

Tutkijoita täytyy motivoida ja kiireellisemmät muutokset liittyvät tieteelliseen viestintään (julkaisut), tutkimuksen arviointiin (vaikuttavuuskertoimet) ja meritoitumisen tapoihin (tekijänoikeus). Esimerkiksi Horizon Europen hakemusten arviointimalli kattaa koko tutkimusprosessin pelkkien julkaisujen ja datan sijaan.

Méndezin mukaan suurimpia pullonkauloja ja työkaluja niiden poistamiseen ovat (I) esteiden poistaminen ja kannustimien luominen (vaihtoehtoinen / seuraavan sukupolven metriikka, tutkimuksen tinkimättömyys, tekstin ja datan louhinta), (2) avoimen tieteen infrastruktuurin kehittäminen (esim. eurooppalaisen avoimen tieteen infrastruktuuri EOSC, European Open Science Cloud) ja (3) avoimen tieteen juurruttaminen yhteiskuntaan (mm. kansalaistiede, julkinen sitouttaminen - tietoyhteistyö yhteiskunnallisiin haasteisiin vastaamiseksi).

Tutkijoita tulisi motivoida rahan ja maineen ohella avoimen tieteen houkuttelevuudella, ja sitä on mahdollista lisätä muun muassa tekemällä avoin tiede hyvin helpoksi, tarjoamalla apua, antamalla tunnustusta ja sallimalla tutkijoiden nauttia avoimesta tieteestä ja uskoa siihen. Koulutus on paras tapa edistää avointa tiedettä.

Postereista avoimeen tietoon kytkeytyi INOs-projektin posteri, jonka aiheena oli kansalaisten sekä korkeakoulujen henkilökunnan ja opiskelijoiden yhteistyö avoimen tiedon ja avointen innovaatioiden avulla.

\section{Avoimen julkaisemisen haasteet tukipalveluiden perusta}

voin julkaisemien keskuste-
luttaa edelleen uusien julkai-
sumallien nostaessa päätään. Eräässä teemaosiossa tarkastelussa oli diamond open access -julkaisumalli, jossa kustantaja ei peri julkaisu- tai kirjoittajamaksuja kuten kultaisen tien mallissa, mutta itse julkaisu on silti välittömästi luettavissa. Itse malli on ollut olemassa jo kauan, mutta se on herättänyt viime aikoina laajempaa keskustelua julkaisukustannusten kasvaessa.

SPARC Europen tekemän tutkimuksen mukaan 4I \% diamond-mallin lehdistä oli yliopistojen rahoittamia ja ylläpitämiä. Tämä tarkoittaa käytännössä, että yliopistoissa on ryhdytty tarjoamaan erilaisia tieteellisen julkaisemisen palveluita joko laajempina kustannuspalveluina, joihin sisällytetään myös toimituksellinen työ tai pelkkien julkaisualustojen tarjoaminen. Molemmissa tapauksissa organisaatioiden henkilöstö voi julkaista julkaisunsa avoimesti ja ilman julkaisu- tai 
kirjoittajamaksuja. Tavoitteena lanseeratuilla palveluilla on tarjota laadukkaita ja taloudellisesti kestäviä ratkaisuja tiedejulkaisemiselle.

Avoin julkaiseminen vaikuttaa julkaisujen käyttämiseen ja niiden saamaan huomioon sekä hyödyttää erityisesti niitä kohderyhmiä, joilla ei ole pääsyä maksumuurien takana oleviin aineistoihin. Eräässä teemaosiossa tarkasteltiin (I) julkaisujen yhteiskunnallista vaikuttavuutta ja sen mahdollistamia seurauksia, (2) miten avointen ja ei-avointen julkaisujen vaikuttavuus eroaa ja mikä merkitys sillä on tiedeyhteisön ulkopuolelle sekä (3) mitä työkaluja voi suositella tutkijoille heidän yhteiskunnallisen vaikuttavuutensa maksimoimiseksi. Erityisesti kiinnitettiin huomiota siihen, että tutkijoita tulee tukea yhteiskunnallisen vaikuttavuuden lisäämisessä, koska erityisesti nuorempi tutkijasukupolvi kokee yhteiskunnallisen vaikuttavuuden moraalisena velvollisuutena.

Suuret muutokset vaativat toimintakulttuurin ja käyttäytymisen muutosta, totesi Massimo Köster, kun puhuttiin avoimen julkaisemisen haasteista. Hän on havainnut käyttäytymiseen liittyvän neljä haastetta. Ensimmäisenä on palkitsevuus: tieteen palkitsevuus on usein sidoksissa esimerkiksi bibliometrisiin mittareihin, ja usein korkean vaikuttavuuskertoimen julkaisut eivät ole avoimia. Toisena on ymmärryksen puute ja vaikutusten aliarviointi, eli ei nähdä niitä hyötyjä, joita tieteellisen tiedon saavutettavuudella voidaan saada esimerkiksi huonommassa rahoitusasemassa olevien maiden tutkijoiden keskuudessa. Kolmantena nousi esiin tietämättömyys avoimen julkaisemisen mahdollisuuksista ja käytettävissä olevista vaihtoehdoista, eli erilaiset mallit ja rahoituskanavat. Viimeisenä havaintona nousi esiin epäilijöiden joukko, joka ei tunnusta avoimen julkaisemisen hyötyjä. Näiden havaintojen pohjalta voidaan tukirakenteita ohjata siten, että ongelmakohtiin voidaan tarjota ratkaisuja.

Postereista julkaisemiseen kytkeytyivät ainakin Helsingin yliopiston kirjasto Open Access Hub, joka käsitteli muun muassa sitä, millaisia haasteita Plan S asettaa yliopistolle julkaisijana, sekä Uppsalan yliopiston kirjaston posteri julkaisusopimusten evaluoinnista.

\section{Data ja ohjelmistot}

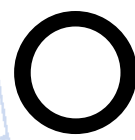
hjelmistojen ja datan kanssa työskentelyä käsittelevässä sessiossa hahmoteltiin kolmen esityksen voimin tutkijoiden ja kirjastojen mahdollisuuksia käyttää FAIR-tietoa ja avointa tietoa. Barbara McGillivray, Nicolas Larrousse ja Daan Broeder keskustelivat siitä, millainen rooli dataviittauksilla ja datan julkaisemisella voisi olla toisaalta tutkijoiden ja kirjastojen synergiassa ja toisaalta yhteiskuntatieteiden ja humanististen tieteiden uusien tutkimustapojen muotoilussa. Lisäksi he esittivät, miten kirjastot voisivat saada datan ja datajulkaisut helposti saataville, miten kirjaston henkilökunta voisi toimia

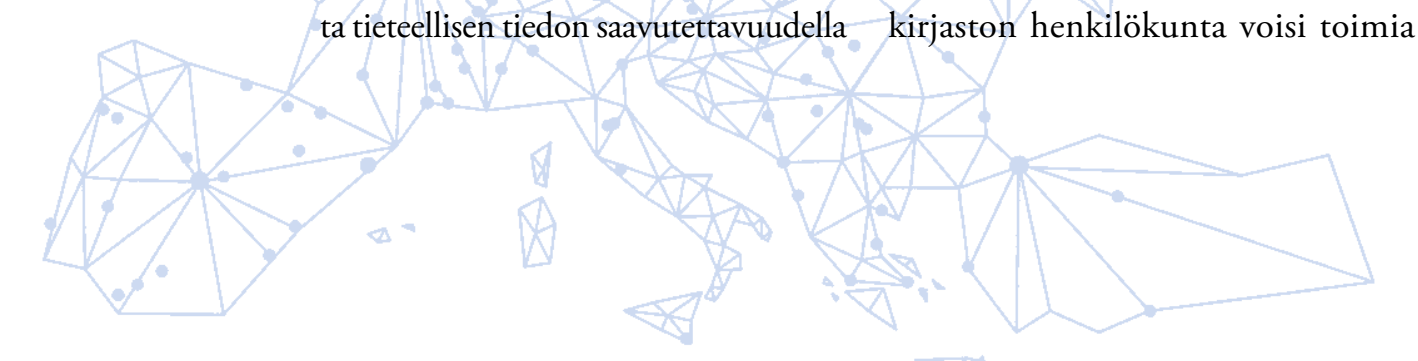


opiskelijoiden ja tutkijoiden kouluttajana parhaiden käytäntöjen suhteen sekä miten datakokoelmat saataisiin parhaiten kuratoitua vastaamaan yhteiskuntatieteiden ja humanististen tieteiden tarpeita.

Session toisessa esityksessä Katie Wilson esitteli Curtin Open Knowledge Initiative (COKI) -hanketta, joka tutkii ja jakaa julkisesti saatavilla olevaa tietoa, analyyseja, oivalluksia ja ohjelmistokoodia lisätäkseen ymmärrystä institutionaalisen tutkimustyön tuloksellisuudesta ja edistymisestä kohti avoimen osaamisen instituutioita. Projektin esittelyn lisäksi kerrottiin erityisesti siitä, miten yhteistyö kirjastojen kanssa voi parantaa institutionaalista ymmärrystä avoimen tutkimuksen tuotannosta, suorituskyvystä ja vaihtoehdoista avoimen tietämyksen oppilaitosten toteuttamiseksi.

Kolmannessa esityksessä Neil Philippe Chue Hong käsitteli ohjelmistojen merkityksen tunnistamista sekä sitä, miten kirjastot voisivat auttaa tutkijoita ohjelmistoviittausten omaksumisessa. Esillä oli ajatus, kuinka tutkimuskirjastot voisivat tehdä yhteistyötä oman talon ohjelmistotuotannon ja tietojenkäsittelyn tutkimusryhmien kanssa ja näin tarjota nykyistä laajempaa tukea avoimelle tutkimukselle,
FAIR-tutkimukselle, toistettavuudelle sekä ohjelmistojen säilymiselle.

Tanskan kuninkaallisen kirjaston posteriaiheena olivat avoimen datan mahdollisuudet ja etenkin tekniset haasteet, kun digitaaliseen aineistoon kuuluu muun muassa yli 35 miljoo-

alkaen, radio- ja tv-lähetyksiä 8o-luvun puolivälistä lähtien, 790 teratavua Tanskan Internet-arkistoa, 5,2 miljoonaa ilmavalokuvaa sekä tietenkin kirjoja, karttoja, käsikirjoituksia, nuotteja ja piirustuksia.

\section{Lopuksi}

Seuraava LIBER-konferenssi järjestetään Odensessa 6.-8.7.2022. Sinne olisi mukava päästä kohtaamaan kollegoita eri maista ja kirjastoista. Virtuaalisiin konferensseihin on helppoa ja edullista osallistua, joten niistä voi yrittää poimia vain itselle relevantit esitykset ja organisaatio voi tarjota osallistumismahdollisuuden monelle työntekijälle. Virtuaalikonferenssit voivat olla ajatuksia herättäviä siinä missä perinteisetkin konferenssit, mutta eivät kuitenkaan anna juurikaan mahdollisuuksia satunnaisiin kohtaamisiin, vie mukanaan konferenssitunnelmaan tai luo vastaavaa kokonaiskuvaa kuin osallistuminen paikan päällä.

\section{Kirjoittajat:}

\author{
Marja KuitTinen \\ Itä-Suomen yliopiston kirjasto \\ marja.kuittinen@uef.fi
}

\author{
Heta Mikkonen \\ Itä-Suomen yliopiston kirjasto \\ heta.mikkonen@uef.fi
}

\section{Tuulevi Ovaska}

Itä-Suomen yliopiston kirjasto tuulevi.ovaska@uef.fi
Katri RintamäKI

Itä-Suomen yliopiston kirjasto

katri.rintamaki@uef.fi
Tomi Rosti

Itä-Suomen yliopiston kirjasto tomi.rosti@uef.fi 